\title{
PODER DE FATO E PODER DE DIREITO NO EXERCÍCIO DA SOBERANIA POPULAR: Da Vontade Geral Como Condição para a Instauração da Democracia Participativa
}

\author{
Luiz Carlos Mariano da Rosa \\ Observatório Político. Rua Almerindo Lessa/Pólo Universitário do Alto da Ajuda - 1349055 - Lisboa/Portugal. \\ http://lattes.cnpq.br/0084141477309738. http://orcid.org/0000-0001-7649-2804. \\ marianodarosaletras@outlook.com
}

RESUMO

Baseada na teoria de Rousseau, a pesquisa assinala que, consistindo na condição sine qua non para o exercício da soberania popular em uma construção que converge para as fronteiras que encerram a Constituição e o Estado, a Vontade Geral envolve a possibilidade de articulação da totalidade dos homens na condição de indivíduos em sua concreticidade histórico-cultural e econômico-social, o que implica a universalidade concreta, que advém do conjunto de vontades e fato econômico que caracteriza a sociedade e a dinâmica das relações intersubjetivas. Dessa forma, fundamentado em uma pesquisa bibliográfica, o artigo dialoga com a perspectiva da teoria institucional de Castoriadis, Lapassade e Lourau, defendendo que, caracterizando-se como um processo ético-jurídico de deliberação coletiva que implica a objetivação dos valores, necessidades e fins do povo como corpo coletivo e moral por meio de um movimento econômico-político que envolve os momentos que encerram o instituído, o instituinte e a institucionalização, a Vontade Geral converte o conteúdo político-social em poder de direito. Assim sendo, convergindo para a superação da universalidade de um Direito que encerra um "dever-ser" e uma exterioridade coercitiva que se impõe em nome do bem comum da totalidade político-jurídica e econômico-social do Estado, a pesquisa mostra que a Vontade Geral se sobrepõe à ruptura que, envolvendo a ordem jurídica e a ordem social, caracteriza a instituição estatal sob a égide do liberalismo, possibilitando a instauração da democracia participativa.

Palavras-chave: vontade geral; soberania popular; Estado; Direito; democracia participativa.

POWER OF FACT AND POWER OF LAW IN THE EXERCISE OF POPULAR SOVEREIGNTY: OF THE GENERAL WILL AS CONDITION FOR THE INSTAURATION OF PARTICIPATIVE DEMOCRACY ABSTRACT

Based on Rousseau's theory, the research points out that, constituting the sine qua non condition for the exercise of popular sovereignty in a construction that converges to the boundaries that enclose the Constitution and the State, the General Will involves the possibility of articulation of the totality of the men as individuals in their historical-cultural and socio-economic concretiality, which implies the concrete universality that comes from the set of wills and economic fact that characterizes society and the dynamics of intersubjective relations. In this way, based on a bibliographical research, the article dialogues with the perspective of the institutional theory of Castoriadis, Lapassade and Lourau, defending that, characterizing itself as an ethico-juridical process of collective deliberation that implies the objectification of values, needs and ends of the people as a collective and moral body through an economic-political movement that involves the moments that enclose the instituted, the institute and the institutionalization, the General Will converts the political-social content into the power of law. Therefore, converging to overcoming the universality of a Law that contains a "duty-to-be" and a coercive exteriority that is imposed in the name of the common good of the political-juridical and economic-social totality of the State, research shows that the General Will overlaps with the rupture that, involving the juridical order and the social order, characterizes the state institution under the aegis of liberalism, enabling the establishment of participatory democracy.

Keywords: general will; popular sovereignty; State; Right; democracy participative.

Recebido em: 25/5/2019

Aceito em: 6/7/2021 


\section{ASPECTOS INTRODUTÓRIOS}

Sobrepondo-se à condição que implica uma soma de caráter puro e simples envolvendo as vontades particulares e que consiste em um resultado que não representa senão a vontade de todos ou da maioria, à Vontade Geral, segundo a leitura de Rousseau, o que se impõe é a distinguibilidade entre o mundo privado, dirigido pelas vontades particulares (que por meio dos atos particulares convergem para as fronteiras dos interesses particulares), e o mundo público, cujo governo está sob o poder da vontade que tende ao horizonte que encerra o interesse geral ou comum e que se manifesta por intermédio dos atos gerais (as leis, no caso), perfazendo "realidades" que assinalam uma separação radical que traz como fundamento a própria natureza de ambas.

Nessa perspectiva, a Vontade Geral, segundo a leitura rousseauniana, converge para assegurar que a soberania não se impõe mediante uma ordem superior de caráter natural ou divino senão por intermédio do próprio povo enquanto tal, que implica uma condição que pressupõe a união das vontades individuais por meio de um contrato que, perfazendo a organização social, para que seja justo não pode se lhes privar do essencial para a existência humana, a saber, a liberdade. A conservação da liberdade, cuja perda ou comprometimento se impõe como uma questão incogitável no tocante ao estabelecimento da organização social, demanda que a soberania não seja exercida senão pelo próprio povo por meio da Vontade Geral, pois se o contrato acarreta uma alienação total é porque carrega a possibilidade de assegurar a sobreposição do coletivo em relação ao individual e, consequentemente, a construção de uma ordem igualitária. ${ }^{1}$

Dessa forma, o pacto por intermédio do qual uma coletividade, sob a acepção que envolve uma pessoa moral, estabelece um engajamento recíproco com seus membros na condição que os encerra individualmente, não pode convergir senão para a conclusão que assinala que se apenas uma das partes guarda possibilidade de não cumprir os compromissos ora assumidos, a saber, no caso dos particulares, o que se impõe ao corpo do povo em via de constituição é a sua impossibilidade de prejudicar os seus membros, à medida que acarretaria o seu próprio prejuízo, visto que mesmo que fosse de um deles as consequências alcançariam todos igualmente. ${ }^{2}$

Extrapolando os limites de um caráter rígido e estático de um fenômeno sempre idêntico a si, a Vontade Geral consiste em um processo que envolve uma relação dialética em sua construção que, por essa razão, longe de supor o aniquilamento do homem na condição de indivíduo e sua vontade particular, demanda a vivência do paradoxo que envolve a sua condição de cidadão por meio de uma construção que assinala que se o poder emerge como suscetível de cessão, o que se impõe à vontade não é senão o seu caráter inalienável, à medida que tal transmissão, convergindo para um pacto de "submissão", inconcebível no tocante ao pacto que engendra a ordem social, destituiria o conjunto dos cidadãos do status de um "povo" propriamente dito, o que implica a impossibilidade acerca da representação da soberania.

\footnotetext{
Na medida em que "o pacto social estabelece entre os cidadãos tal igualdade, que eles se comprometem todos nas mesmas condições e devem gozar todos dos mesmos direitos. Igualmente, devido à natureza do pacto, todo o ato de soberania, isto é, todo o ato autêntico da vontade geral, obriga ou favorece igualmente todos os cidadãos, de modo que o soberano conhece unicamente o corpo da nação e não distingue nenhum dos que a compõem" (ROUSSEAU, 1999b, p. 97 et seq.).

2 "Enquanto os súditos só estiverem submetidos a tais convenções, não obedecem a ninguém, mas somente à própria vontade, e perguntar até onde se estendem os direitos respectivos do soberano e dos cidadãos é perguntar até que ponto estes podem comprometer-se consigo mesmos, cada um perante todos e todos perante cada um" (ROUSSEAU, 1999b, p. 97 et seq.)
} 


\section{Democracia}

À impossibilidade de que a vontade seja alienada o que se impõe não é senão, concomitantemente, a sua indivisibilidade, à medida que o seu fracionamento se lhe atribui caráter particular em um processo que encerra a Vontade Geral como um momento do todo, o que requer uma síntese das determinações histórico-culturais e econômico-sociais que caracterizam a vida dos homens como indivíduos concretos no âmbito do corpo coletivo e moral e os perfazem como tais, convergindo para a objetivação de valores, necessidades e fins por intermédio de um movimento que, abrangendo o instituído, o instituinte e a institucionalização, ${ }^{3}$ impõe-se à organização do poder, à ordem político-jurídica e à instituição do Estado.

Nessa perspectiva, a Vontade Geral ${ }^{4}$ constitui-se no veículo da manifestação dos interesses que, no que respeita aos indivíduos, cada um tem em comum em relação aos demais, convergindo para a conclusão de que o seu atendimento envolve menos a parte do que o todo, tendo em vista que emerge como a tradução do que há de comum em todas as vontades individuais, perfazendo, em suma, a unificação da multiplicidade dos contratantes, não convergindo senão, dessa forma, para as fronteiras que encerram o próprio sentido da democracia. ${ }^{5}$

A possibilidade de que o Estado supere a condição que atrela o seu poder ao conceito de uma "força arbitrária", eis o que compete à Vontade Geral, à medida que se o ordenamento e a composição da forma institucional estatal guardam raízes em um determinado sistema político-jurídico, ${ }^{6}$ o que se lhe impõe é a Constituição, para a qual converge o processo que envolve as decisões coletivas e, antes, a sua deliberação,7 o que implica o exercício de uma "força institucionalizada" que sob a acepção de um poder sociopolítico e jurídico acena com a capacidade do povo de autogoverno e com o diálogo entre as relações e normas, reprodução e produção, so-

\footnotetext{
Perfazendo o resultado envolvendo um conflito incessante entre o instituído e o instituinte, segundo Lourau (1996), a instituição guarda correspondência, em suma, com um processo, convergindo para as fronteiras que encerram uma produção social, o que implica um movimento que, trazendo como base a concreticidade de um determinado estrato natural disposto, caracteriza-se pela relação dialética que atribui à sociedade a condição de "autoalteração perpétua", de acordo com Castoriadis (1986), que supõe um processo cuja manifestação se desenvolve por meio de uma posição que carrega fixidez e estabilidade relativas e da emergência de uma ruptura que tende a engendrar outra forma de ser de uma instituição que consiste intrinsecamente em história.

4 "Um ato puro do entendimento" que implica, em cada indivíduo, um raciocínio que emerge do silêncio das paixões. À Vontade Geral, segundo Diderot, cabe o exercício do poder Legislativo, cuja perspectiva influencia a leitura rousseauniana na construção da referida teoria (a saber, que envolve a Vontade Geral), para a qual converge também a visão de Spinoza, que se detém na questão que se refere à "mente comum" e à impossibilidade de que o Estado venha errar, embora, nesse caso, correspondendo à lógica que assinala por que não conhece um poder que se the sobreponha, superando-o.

5 Cabe salientar que "se as 'regras do jogo' perfazem uma condição necessária para a instauração da democracia, o que se impõe ao seu exercício é mais do que as formas de representação que a caracteriza no âmbito do liberalismo senão também a construção de institutos que possibilitem um processo direto, participativo, além da criação de instrumentos jurídicos e econômico-sociais que viabilizem a sua prática, convergindo para a emergência do viés subversivo e anticapitalista em cujas fronteiras guarda raízes e sobrepujando a definição minimalista que a ideologia (burguesa) se lhe atribui" (MARIANO DA ROSA, 2014, p. 125).

6 "Como idéia-limite, o programa liberal cria o Estado ético, isto é, um Estado que idealmente está acima das competições de classe, do cruzamento e choque dos agrupamentos que compõem a realidade econômica e tradicional. Este Estado é mais uma aspiração política do que uma realidade política; existe apenas como modelo utópico, mas este seu ser é precisamente uma miragem que o torna robusto e o transforma numa força de conservação. Na esperança que ele se realize finalmente na sua completa perfeição, muitos encontram a força para o não renegarem e, portanto, para não procurarem substituí-lo" (GRAMSCI, 1976, p. 115).

Eis os princípios expostos por Gramsci em relação ao momento em questão: "Os componentes da colectividade devem, portanto, pôr-se de acordo, discutir entre eles. Através da discussão, deve resultar uma fusão dos espíritos e das vontades. Os elementos singulares de verdade, que cada um pode oferecer, devem sintetizar-se na complexa verdade e ser a expressão integral da razão. Para que isto se realize, para que a discussão seja exaustiva e sincera, é necessária a máxima tolerância. Todos devem estar convencidos que aquela é a verdade e que, portanto, é preciso necessariamente pô-la em prática" (GRAMSCl, 1976, p. 172, grifos do autor).
} 
berania e direito, forma e conteúdo, que contempla valores, necessidades e objetivos do corpo coletivo e moral por intermédio da articulação na instância institucional dos momentos do instituído, do instituinte e da institucionalização, estabelecendo a correspondência entre a legislação e a realidade da vida dos homens em sua concreticidade histórico-cultural e econômico-social que a realização ou a construção da democracia como ordem sociopolítica e jurídica demanda.

A convergência para a igualdade, eis a tendência que caracteriza a Vontade Geral que, segundo a sua natureza, contrapõe-se ao caráter das vontades particulares, que não encerram senão as predileções individuais, o que inviabiliza um acordo constante, demandando tal relação que a Vontade Geral, soberana, se sobreponha às vontades particulares em um processo que atribui à Vontade Geral a exteriorização da subjetividade coletiva do Estado (ich-kollektivität) e a subjetividade dos indivíduos na condição de membros da organização social (ich-individualität), encerrando em si a possibilidade de conciliar o antagonismo para o qual convergem, cuja superação a sua objetivação assegura. ${ }^{8}$

Se à infalibilidade da Vontade Geral o que se impõe não é senão o postulado que encerra a noção de que o povo incorporado quer sempre e necessariamente o bem comum, que implica simultaneamente todos e cada um, segundo a leitura de Rousseau, a unidade que caracteriza em seu princípio a Vontade Geral guarda correspondência com a impossibilidade de se dividir a soberania por meio de um movimento reducionista, nem tampouco, mantendo a referida perspectiva, fazê-la seu objeto. ${ }^{9}$

Carregando a possibilidade de que os homens na condição de indivíduos em sua concretude histórico-cultural e econômico-social não sejam relegados à margem da ordem sociopolítica, cuja instituição é constituída por valores, necessidades e objetivos que emergem das relações sociais engendradas no âmbito das forças produtivas, a Vontade Geral converge para um sentido de organização que se sobrepõe à noção que mantém estas em condição de exterioridade no que se lhe concerne, como se as formas institucionais não se lhes guardassem raízes, configurando uma es-

\footnotetext{
8 Tendo em vista a leitura que assinala que "cada um dando-se a todos não se dá a ninguém e, não existindo um associado sobre o qual não se adquira o mesmo direito que se lhe cede sobre si mesmo, ganha-se o equivalente de tudo o que se perde, e maior força para conservar o que se tem" (ROUSSEAU, 1999b, p. 70 et seq.).

9 Contrapondo-se à concepção de soberania desenvolvida por meio do idealismo de Hegel, Marx afirma: "Como se o povo não fosse o Estado real. O Estado é um abstractum. Somente o povo é o concretum. E é notável que Hegel atribua sem hesitação uma qualidade viva ao abstractum, tal como a soberania, e só o faça com hesitação e reservas em relação ao concretum" (MARX, 2010, p. 48, grifos do autor). Dessa forma, recorrendo ao texto de Hegel, Marx salienta que, atribuindo ao conceito de soberania duas definições opostas, o filósofo do idealismo absoluto relaciona a soberania popular à noção que encerra "pensamentos confusos", e "representação desordenada". Eis a citação de Hegel e a crítica de Marx: "Mas soberania popular, definida em oposição à soberania existente no monarca, é o sentido ordinário em que se começou a falar de soberania popular nos últimos tempos - nessa oposição a soberania popular pertence aos pensamentos confusos, em cujo fundamento reside a representação desordenada do povo.

Os 'pensamentos confusos' e a 'representação desordenada' encontram-se, aqui, somente em Hegel. Certamente: se a soberania existe no monarca, é uma estupidez falar em uma soberania oposta existente no povo, pois é próprio do conceito de soberania que ela não possa ter uma existência dupla, e muito menos oposta" (MARX, 2010, p. 48, grifos do autor).

E Marx conclui, esclarecendo que: "Mas:

1) a questão é, precisamente, a seguinte: não é uma ilusão a soberania absorvida no monarca? Soberania do monarca ou do povo, eis a question.

2) pode-se falar, também, de uma soberania do povo em oposição à soberania existente no monarca. Mas, então, não se trata de uma única e mesma soberania, nascida de ambos os lados, mas de dois conceitos absolutamente contrapostos de soberania, dos quais um é tal que só pode chegar à existência em um monarca, e o outro tal que só o pode em um povo. Do mesmo modo em que se pergunta: é Deus o soberano, ou é o homem o soberano? Uma das duas soberanias é uma falsidade, ainda que uma falsidade existente" (MARX, 2010, p. 49, grifos do autor).
} 
pécie de arcabouço existente a priori e ao qual se impõe uma integração que demanda o exercício da coação ${ }^{10}$ que, indispensável à sua sobrevivência como tal, torna sem efeito (supérfluo) o acordo tácito ou formulado que transforma um conjunto de indivíduos em seus membros.

\section{DA VONTADE GERAL COMO UM PROCESSO ÉTICO-JURÍDICO DE DELIBERAÇÃO COLETIVA E MOVIMENTO ECONÔMICO-POLÍTICO DE INSTITUCIONALIZAÇÃO DO PODER: PODER DE FATO E PODER DE DIREITO NO EXERCÍCIO DA SOBERANIA POPULAR}

À ruptura envolvendo a ordem jurídica e a ordem social (político-social), que converge para atribuir uma condição de justaposição a ambas no âmbito das relações que as caracterizam e as distinguem como tais em uma conjuntura que as encerram como duas expressões do funcionamento da totalidade social, o que se impõe é a Vontade Geral como um processo ético-jurídico de deliberação coletiva que implica a objetivação de valores, necessidades e fins do povo como corpo coletivo e moral por meio de um movimento econômico-político que envolve os momentos que encerram o instituído, o instituinte e a institucionalização ${ }^{11}$ e que guarda possibilidade de se sobrepor às distinções abstratas do pensamento que dialoga com o ideal liberal da Justiça e o seu caráter conservador. Tal ideal tende a "desprezar" a dinâmica das relações sociais, interindividuais, intersubjetivas, e "sacrificar" a sua vitalidade em nome da formalidade tecnicista que mantém raízes em um viés antropológico reducionista, que pressupõe o Estado sob a acepção de uma totalidade ético-jurídica e econômico-política ${ }^{12}$ que transcende a sociedade e corresponde às aspirações, não dos indivíduos concretos que a perfazem, mas da sua "essência", como se esta representasse uma realidade "transcendental" e não a substantivação dos fenômenos das vivências histórico-culturais e econômico-sociais dos seres humanos. ${ }^{13}$

\footnotetext{
${ }^{10}$ Baseado no direito de propriedade o sistema social converge para a construção de relações que, envolvendo os homens na condição de indivíduos em sua concretude histórico-cultural e econômico-social entre si, não se caracterizam senão como uma sequência ilimitada de reparações e represálias, perfazendo uma organização político-jurídica cujo poder se impõe por meio da violência que, guardando correspondência com o próprio recurso instaurador da "sociedade civil", consiste, em função da sua "força", na única alternativa capaz de viabilizar a paz, convergindo para as fronteiras que implicam que "a colocação das técnicas do poder capitalista, a constituição dos dispositivos disciplinares, a emergência das instituições ideológico-culturais, pressupõem a monopolização da violência pelo Estado, recoberta precisamente pelo deslocamento da legitimidade para a legalidade e pelo reino da lei" (POULANTZAS, 1981, p. 91.)

${ }^{11}$ Se o instituinte consiste em um momento do processo de institucionalização que encerra o movimento de produção do sistema de valores, necessidades e fins que converge, nas fronteiras da instituição, para a constituição do instituído, o instituído configura a condensação do conteúdo que emerge do instituinte, o que implica que, nesta relação, "o instituinte aparece como um processo, enquanto o instituído aparece como resultado" (LAPASSADE, 1989, p. 30).

${ }^{12}$ Alcança relevância, nesta perspectiva, o esclarecimento de Kosik acerca da noção de totalidade segundo o método dialético: "O ponto de vista da totalidade concreta nada tem de comum com a totalidade holística, organicista ou neo-romântica, que hipostasia o todo antes das partes e efetua a mitologização do todo. A dialética não pode entender a totalidade como um todo já feito e formalizado, que determina as partes, porquanto à própria determinação da totalidade pertencem a gênese e o desenvolvimento da totalidade, o que, de um ponto de vista metodológico, comporta a indagação de como nasce a totalidade e quais são as fontes internas do seu desenvolvimento e movimento. A totalidade não é um todo já pronto que se recheia com um conteúdo, com as qualidades das partes ou com as suas relações; a própria totalidade é que se concretiza e esta concretização não é apenas criação no conteúdo mas também criação do todo" (KOSIK, 1976, p. 58 et seq., grifos do autor).

${ }^{13}$ Tendo em vista que, segundo Nicos Poulantzas, "Este Estado apresenta-se como Estado-popular-de-classe. Suas instituições apresentam-se como organizadas em torno dos princípios da liberdade e da igualdade dos indivíduos. A legitimidade deste estado se baseia no conjunto de 'indivíduos-cidadãos formalmente livres e iguais', na soberania popular e na responsabilidade laica do Estado para com o povo. O próprio 'povo' é erigido em princípio de determinação do Estado, não enquanto composto por agentes da produção distribuídos em classes sociais, mas enquanto massa de indivíduos cidadãos, cujo modo de participação em uma comunidade política nacional se manifesta no sufrágio universal, expressão da 'vontade geral'" (POULANTZAS, 1977, p. 119).
} 
Se a ordem político-jurídico se impõe à relação do homem como indivíduo concreto diante do mundo, convergindo para institucionalizar as fronteiras que pretendem distinguir ambas as "realidades", simultaneamente possibilitando o intercâmbio devido, desde que de acordo com o horizonte de normas e prescrições em questão, o que cabe à Vontade Geral é a instauração de um processo que se sobrepõe às noções de interioridade e exterioridade no que respeita à instituição social e às formas que se lhe estão atreladas, superando, no que se relaciona ao sujeito em si, a concepção que se lhe atribui a condição que pressupõe a "interiorização" dos valores e práticas, condutas e comportamentos, necessidades e finalidades, como fundamento do sistema institucional que, nesta perspectiva, detém o "direito" de exercer o poder da "coação incondicionada", que se torna, pois, indispensável à sua sobrevivência como tal.

Consistindo no direito absoluto do corpo coletivo e moral, a Vontade Geral não se impõe senão como condição para o exercício da soberania popular, convergindo, em razão do processo que envolve as decisões coletivas e, antes, a sua elaboração, para as fronteiras que encerram a Constituição ${ }^{14}$ e o Estado que dela emerge na dialética que implica os momentos que encerram o instituído, o instituinte e a institucionalização por meio de um movimento que perfaz a sua totalidade enquanto tal e traz o povo real como fundamento.

Nessa perspectiva, o que cabe à Vontade Geral é a possibilidade de superação da ruptura entre o Estado e a sociedade civil, que representam, respectivamente, o Estado político e o Estado não político, na medida em que impede que a Constituição, que tende a corporificar a Vontade Geral através das leis para as quais converge a sua manifestação nas assembleias, interponha-se entre o povo (o "todo", o poder constituinte) e a sua própria "essência". Essa "essência" é suposta em sua existência que, como tal, assegura a preeminência do interesse comum em face dos interesses particulares que se the opõem, o que implica a sobreposição da alienação política, que não envolve senão a inversão das posições abrangendo o povo ("Estado real") e a Constituição (Estado político), tendo em vista que aquele, destituído do seu conteúdo genérico, perde seu estatuto fundante, tornando-se refém deste último, sua própria criação (MARIANO DA ROSA, 2015b, p. 20 et seq.).

Emergindo como limite para o exercício da subjetividade absoluta a Vontade Geral encerra uma condição que, guardando raízes nas fronteiras de um humanismo abstrato, dialoga com a manifestação de uma individualidade prenhe de uma concepção antropológica baseada em uma construção metafísica e trans-histórica que converge para uma ordem social que implica a justaposição de "consciências" e vontades, como se houvesse possibilidade de que cada qual se mantivesse imune ao processo intersubjetivo, ao outro, no âmbito das relações do sistema produtivo, sobrepondo-se à universalidade concreta que advém do conjunto de vontades e fato econômico que caracteriza a verdadeira coexistência "humana".

Possibilitando que o corpo coletivo e moral exerça o controle das suas condições de existência, a Vontade Geral envolve um processo que viabiliza a intervenção direta do povo

\footnotetext{
14 "Por certo, Rousseau não nega que o Estado possa dar-se uma constituição, mas, para ele, essa constituição só existe pela vontade do soberano, o qual pode mudá-la quando lhe apraz. As leis do Estado, inclusive as leis fundamentais, são apenas a expressão da vontade geral. Basta, portanto, que essa vontade mude para que as leis estabelecidas sejam revogadas e substituídas por outras: a autoridade que as dita pode também aboli-las" (DERATHÉ, 2009, p. 483).
} 
no destino dos homens na condição de indivíduos em sua concretude histórico-cultural e econômico-social, sobrepondo-se à abstração que caracteriza a concepção que se lhe atribui "naturalidade", assinalando a divisão do trabalho ${ }^{15}$ - e a dependência universal que lhe é decorrente - como uma forma de colaboração universal inevitável, que converge para a construção de um poder cuja noção escapa aos próprios agentes envolvidos, como se representasse um fenômeno que encerra um movimento desenvolvido sem o protagonismo dos sujeitos em sua vida efetiva.

Conforme os princípios da inalienabilidade do poder de determinar as regras (isto é, a "soberania" do trabalho não como uma classe particular, mas como condição universal da sociedade) e da delegação de papéis e funções sob regras bem específicas, definidas, flexivelmente distribuídas e adequadamente supervisionadas, o estabelecimento de uma forma socialista de tomada de decisão exigiria invadir e reestruturar radicalmente os domínios materiais antagônicos do capital. Um processo que deveria ir bem além do princípio da soberania popular inalienável de Rousseau e seu corolário delegatório. Ou seja, numa ordem socialista, o processo "legislativo" deveria ser fundido ao próprio processo de produção de tal modo que a necessária divisão horizontal do trabalho (...) fosse complementada em todos os níveis, do local ao global, por um sistema de coordenação autodeterminado do trabalho. Esta relação contrasta agudamente com a perniciosa divisão vertical do trabalho do capital, que é complementada pela "separação dos poderes" em um "sistema político democrático" alienado e inalteravelmente imposto às massas trabaIhadoras (MÉSZÁROS, 2011, pp. 828 et seq., grifos do autor)

Convergindo para a superação das particularidades que caracterizam os homens como indivíduos em sua concretude histórico-cultural e econômico-social, a Vontade Geral tende à construção de uma universalidade que escapa à abstração ${ }^{16}$ e emerge através do próprio movimento da vida, à medida que implica uma condição que possibilita, no tocante aos sujeitos, a realização da consciência de si, tornando-os empiricamente universais, não mediante uma "soma de consciências" ou de uma "força objetiva", mas sobrepondo-se ao arbítrio e ao determinismo, por intermédio de uma relação dialética que acena com o horizonte de uma autêntica intersubjetividade.

Nesta perspectiva, a Vontade Geral emerge como um processo ético-jurídico que implica a ordenação dos homens como indivíduos em sua concretude histórico-cultural e econômico-social em relação ao Estado como uma totalidade sociopolítica e jurídica por intermédio

\footnotetext{
${ }^{15}$ Cabe registrar, nessa perspectiva, a crítica de Proudhon acerca do referido desequilíbrio econômico-social: "Se o trabalho é a fonte de toda a riqueza, se é o guia mais seguro para seguir-se a história dos estabelecimentos humanos sobre a face do globo, como a igualdade na distribuição, a igualdade na medida do trabalho, não seria uma lei?

$\mathrm{Se}$, ao contrário, existem riquezas que não provêm do trabalho, como a posse destas riquezas é um privilégio? Qual é a legitimidade do monopólio? Que se exponha pois, de uma vez por todas, esta teoria do direito ao consumo improdutivo, esta jurisprudência do belprazer, esta religião da ociosidade, prerrogativa sagrada de uma casta de eleitos!" (PROUDHON, 2003, p. 173).

${ }^{16}$ Haja vista a perspectiva que assinala que "a dialética de universal e particular na sociedade tem uma função de grande monta; o particular representa aqui, precisamente, a expressão lógica das categorias de mediação entre os homens singulares e a sociedade", conforme esclarece Lukács, que conclui: "Assim, Marx - nos Manuscritos Econômico-Filosóficos - diz: 'Deve-se evitar, sobretudo, fixar a 'sociedade' como uma abstração em face do indivíduo. O indivíduo é ente social. A sua manifestação de vida - mesmo que não apareça na forma direta de uma manifestação de vida comum, realizada ao mesmo tempo com outros - é, portanto, uma manifestação e uma afirmação de vida social. A vida individual e a vida genérica do homem não são distintas, ainda que - necessariamente - o modo de existência da vida individual seja um modo mais particular ou mais geral de vida genérica, e a vida genérica seja uma mais particular ou mais geral vida individual'” (LUKÁCS, 1978, p. 93, grifos do autor).
} 
da integração dinâmico-dialética para a qual converge o movimento econômico-político que encerra os momentos que se impõem à universalidade, à particularidade e à singularidade ${ }^{17}$ que se lhe constituem como tal, perfazendo uma conjuntura que escapa à dissolução dos membros do corpo coletivo e moral em seu arcabouço e tende às fronteiras que acenam com uma diferenciação progressiva entre as subjetividades empíricas que, longe de diluir os vínculos interindividuais, consubstanciam um liame de ordem ético-política por intermédio da consciência da interdependência que advém em razão da condição de cidadão e súdito que simultaneamente assume o sujeito em sua existência coletiva e em sua vida histórico-cultural.

Resultando do movimento econômico-político que encerra os momentos do instituído, do instituinte e da institucionalização, e do processo ético-jurídico de deliberação coletiva que por meio dele desenvolve-se no sentido que implica a correlação envolvendo a universalidade, a particularidade e a singularidade e perfaz a totalidade sociopolítica e jurídica da sua forma institucional, o Estado não consiste senão em uma unidade concreta que emerge da ação histórico-social e traduz um complexo de valores que se caracteriza como base para o exercício do poder que corporifica como tal em uma composição dialética que converge para as fronteiras de uma representação que encerra a noção de bem comum.

Nessa perspectiva, como instância da correlação envolvendo legalidade e moralidade, a Vontade Geral converge para uma síntese que, longe de eliminar a distinção que as caracteriza, implica a superação que se lhes atribui condição de complementaridade e possibilita que o Direito conserve uma autonomia que não permite, contudo, a sua sobreposição no que concerne ao poder, ao Estado, ao povo.

Se cabe ao Estado um poder cujo exercício converge, em última instância, para as fronteiras que encerram a capacidade de criação do Direito em sua forma e materialidade, o que implica a manifestação de uma vontade que, transcendendo a vida histórico-cultural e econômico-social dos homens em sua concreticidade, se lhes mantém sob a égide de uma relação de exterioridade coercitiva, à condição atribuída a instituição estatal como pessoa coletiva e soberana o que se impõe é a intersecção que entre poder de fato e poder de direito a Vontade Geral como um processo ético-jurídico de deliberação coletiva encarna e que, por meio do movimento econômico-político que encerra a sua instauração, não instrumentaliza senão a soberania popular. ${ }^{18}$

\footnotetext{
${ }_{17}$ Recorrendo à perspectiva de Lourau (1996), cabe esclarecer que, em última instância, se o conceito de instituição, em seu momento da universalidade, guarda correspondência com o conteúdo da ideologia, dos sistemas de normas, dos patterns (padrões), dos valores que guiam a socialização, em seu momento da particularidade não perfaz senão o conjunto das determinações materiais e sociais que converge para negar a universalidade imaginária do primeiro momento, emergindo o referido conceito, em seu momento de singularidade, sob a égide das formas organizacionais, jurídicas ou anômicas, que se impõem como necessárias para atingir um determinado objetivo ou finalidade.

18 "Que será, pois, propriamente, um ato de soberania? Não é uma convenção entre o superior e o inferior, mas uma convenção do corpo com cada um de seus membros: convenção legítima por ter como base o contrato social, equitativa por ser comum a todos, útil por não poder ter outro objetivo que não o bem geral, e sólida por ter como garantia a força pública e o poder supremo" (ROUSSEAU, 1999b, p. 98)
} 


\section{DA VONTADE GERAL COMO UM PROCESSO ÉTICO-JURÍDICO DE OBJETIVAÇÃO DOS VALORES, NECESSIDADES E FINS DO POVO ENQUANTO CORPO COLETIVO E MORAL: da integração dinâmico-dialética à totalidade sociopolítica e jurídica}

Se a história humana emerge sob a condição que caracteriza o homem como um ser que se exterioriza, necessitando, para a sua realização, tanto dos outros quanto da natureza, guardando uma particularidade que, em virtude da posse de determinados bens (simbólicos e "concretos"), converge para uma situação de antagonismo no que respeita aos semelhantes, a Vontade Geral não se impõe senão como possibilidade de superação do problema da coexistência humana, à medida que consiste em um processo que se sobrepõe à subjetividade absoluta, escapando ao racionalismo que, como um fenômeno ideológico, defende a existência de uma moral universal a priori, cuja demanda, no tocante à reconciliação dos homens entre si e a eliminação da oposição e do paradoxo que a vida coletiva supõe, implica a sua correspondência à "boa vontade" kantiana.

Nesta perspectiva, a Vontade Geral consiste em um processo que envolve a institucionalização do conjunto das regras que, em última instância, convergem para a definição do uso que compete à coletividade desenvolver no que diz respeito ao substrato material, produto do investimento dos homens na condição de indivíduos em sua concretude histórico-cultural e econômico-social na construção da história que, longe de se circunscrever à justaposição de "consciências de si", de "eus" e seus interesses privados, guarda um sentido que supõe a inter-relação de consciências situadas sob uma condição de envolvimento com a própria situação que tendem a assumir, se lhes tornando inescapável em um contexto cuja lógica mostra que a ação individual carrega um compromisso que não se esgota em si, mas alcança todos quantos, afirmando-a ou negando-a, mantêm-se no horizonte inevitável que os seus efeitos circunscreve.

Guardando possibilidade acerca da instauração de uma relação dialética envolvendo a história em ato e a história em ideia, a Vontade Geral converge para as fronteiras que encerram a transformação em vida das concepções abstratas em um processo que implica a construção da consciência ${ }^{19}$ por meio da experiência dos homens na condição de indivíduos em sua concretude histórico-cultural e econômico-social na esfera do jogo das forças produtivas. ${ }^{20}$ Dessa forma, constituindo-se um processo que, implicando as decisões coletivas e, antes, a sua elaboração, a Vontade Geral consiste no exercício que possibilita que o corpo coletivo e moral guarde a capacidade de criar o seu destino em lugar de sofrê-lo passivamente.

\footnotetext{
${ }^{19}$ Na medida em que, conforme esclarece Poulantzas, "o Homem é um ser-no-mundo; é uma pura privação subjetiva, carência, necessidade, desejo de algo diferente de si, de uma natureza que o rodeia e que ele precisa conquistar para a satisfação de suas necessidades e desejos. A natureza, o mundo, nega o homem; ser hostil é o primeiro momento dialético da existência humana, o momento da pura subjetividade. O homem, no segundo momento da antítese, exterioriza-se e se objetiva em suas ações; ele nega o mundo, conquista-o, submete-o a seus fins: sua consciência 'retorna' a si mesma, na terceira fase da síntese, enriquecido o seu significado objetivo, reconhecendo-se em suas obras e suas ações, conciliando-se com o mundo" (POULANTZAS, 1965, p. 90).

${ }^{20}$ Tendo em vista que “(o) sistema social socialista não deve e nem pode ser senão um produto histórico, nascido da própria escola da experiência, nascido na hora da sua realização, resultando do fazer-se da história viva (...). O socialismo, por sua própria natureza, não pode ser outorgado nem introduzido por decreto. Ele pressupõe uma série de medidas coercitivas, contra a propriedade, etc. Pode-se decretar o negativo, a destruição, mas não o positivo, a construção" (LUXEMBURGO, 1991, p. 92).
} 
Nesta perspectiva a virtude, segundo a leitura rousseauniana, não consiste senão em uma relação dialética envolvendo a moral individualista, que caracteriza o sistema contratual que se impõe como fundamento da ordem sociopolítica, e a moral cívica, que implica o princípio da república, de acordo com a perspectiva de Montesquieu, convergindo, dessa forma, para a construção da Vontade Geral que, como veículo de expressão do interesse comum, guarda correspondência com um processo que abrange o conhecimento do bem geral (ou bem comum), sob a acepção de uma espécie de viés paradigmático que surge para possibilitar o exercício da soberania mediante a elaboração do arcabouço de leis e normas responsáveis pela dinâmica e pelo equilíbrio da vida da comunidade, enfim, pela sua existência como tal.

Longe de se caracterizar como uma abstração destituída de qualquer valor prático, o que se impõe à Vontade Geral e ao seu exercício não é senão a possibilidade de fixação dos fins políticos que se lhe mantêm inerentes através de uma correlação que implica as lutas da opinião pública, as eleições, as discussões parlamentares, os plebiscitos, dentre outros eventos que convergem para a constituição de um sistema dinâmico-dialético que perfaz a unidade da ordem sociopolítica e expressa o interesse comum, sobrepondo-se à estaticidade que exclui a participação ativa do povo na construção da referida experiência (MARIANO DA ROSA, 2015b, p. 22)

Da necessidade de superação de um conceito de interesse comum atrelado a sua forma institucional, eis o que se impõe ao Estado que, no que se relaciona aos reais interesses particulares e coletivos, mantém condição de independência, convergindo para uma trans-historicidade que tende a estabelecer uma relação de exterioridade coercitiva envolvendo o Estado e a sociedade, à medida que pressupõe os homens como individualidades abstratas e consciências justapostas organizadas sob a égide de um poder que, transcendendo a realidade concreta da vida histórico-cultural e econômico-social, detém a capacidade de realizar a adaptação dos sujeitos à universalidade abstrata que caracteriza a sua constituição. ${ }^{21}$

À Vontade Geral como um processo ético-jurídico de deliberação coletiva que se desenvolve por intermédio do movimento econômico-político de objetivação de valores, necessidades e fins do corpo coletivo e moral e converge para a totalidade sociopolítica e jurídica do Estado, o que se impõe é uma forma institucional que implica a inter-relação fundamental envolvendo todos os aspectos constitutivos da realidade que abrange desde a vida histórico-cultural até a vida econômico-social e encerra a interdependência dos homens na condição de indivíduos em sua concretude como membros do sistema, se lhes atribuindo a responsabilidade moral tanto na esfera particular quanto na esfera coletiva concernente à construção de uma organização igualitária. Tal organização implica a capacidade de autogoverno (autoges-

\footnotetext{
${ }^{21} \mathrm{Na}$ medida em que "o sistema jurídico moderno, distinto da regulamentação feudal baseada em privilégios, reveste um caráter 'normativo', expresso em um conjunto de leis sistematizadas a partir dos princípios de liberdade e igualdade: é o 'reino' da lei. A igualdade e a liberdade dos indivíduos-cidadãos residem na sua relação com as leis abstratas e formais, as quais são tidas como enunciando essa vontade geral no interior de um 'Estado de direito'. O Estado capitalista moderno apresenta-se, assim, como encarnando o interesse geral de toda a sociedade, como substancializando a vontade desse 'corpo político' que seria a 'nação'” (POULANTZAS, 1977, p. 119)
} 
tão) ${ }^{22}$ tendo em vista que uma ordem que priorize uma parcela da sociedade em detrimento de outra e exclua da noção de bem comum a condição originária de codependência dos seres humanos que a integram tende à autodestruição, à medida que supõe uma independência abstrata baseada na justaposição de consciências e no exercício de uma liberdade que não pode transcender a subjetividade, posto que ilimitada, infinita, como um fenômeno existente a priori, trans-histórico, transpessoal, trans-humano, haja vista que

... as coisas mais profundas, as mais importantes, as mais duráveis, não foram ditas pelos "Civilizadores, mas pelos "selvagens" que de repente saíram do fundo da sociedade... 0 exemplo que mais me interessa é o da criação de novas formas institucionais. É preciso que os operários parisienses façam a Comuna... É preciso que o povo russo crie os soviets... Na Hungria ninguém 'ensinou' as pessoas... os operários formaram conselhos de fábrica. Todas essas formas não foram nem preditas, nem deduzidas de uma teoria qualquer; elas foram criadas pelas pessoas, em sua luta e através dela (CASTORIADIS, 1983, p. 241s)

Sobrepondo-se à condição de um valor que pertence a todos em virtude da união que os caracteriza na constituição da organização social, o bem comum se impõe aos homens enquanto indivíduos em sua concretude histórico-cultural e econômico-social como membros da totalidade sociopolítica e -jurídica ora designada como Estado, ${ }^{23}$ à medida que a sua noção depende da relação que nesta perspectiva os tais mantêm, não consistindo em um mero somatório dos bens individuais nem tampouco a sua negação, configurando uma unidade sintética que escapa ao ideal de uma concepção a priori, metafísica e trans-histórica, e tende a corresponder, por meio do funcionamento da forma institucional estatal e das suas atividades, às necessidades e aos objetivos atrelados ao conceito de cidadania ${ }^{24}$ e ao seu exercício. ${ }^{25}$

Resultante da superação do antagonismo envolvendo as vontades particulares e os seus interesses, o bem comum converge para um conceito que, encerrando o fim para cujas fronteiras tende a organização social, implica uma noção universal de justiça que longe de

\footnotetext{
${ }^{22}$ Tendo em vista a perspectiva que sublinha que "[...] cada um, determinando-se livremente por adesão ao que compreende ser o melhor para si mesmo, encontra todos os outros sujeitos racionais para ajustar livremente a instituição do mesmo contrato que realiza a Vontade Geral. Assim, todos os membros do corpo social se dão a si mesmos (criam contratualmente) uma lei geral (e isso será a autonomia) que os organiza sem gerar entre eles diferenças de poder, num sistema federal cuja 'circunferência está em toda parte, o centro em parte alguma'” (GUILLERM; BOURDET, 1976, p. 52).

23 “Portanto, só quando assume um certo 'caráter' específico é que cada indivíduo passa a incluir um membro do corpo soberano - o qual não é mera agregação de indivíduos em suas particularidades. Ao ser membro do corpo soberano, cada indivíduo deve considerar somente o interesse comum de que compartilha com outros indivíduos iguais a ele; deve considerar-se, e julgar e decidir, somente como um 'componente do povo'" (DENT, 1996, p. 90).

${ }^{24}$ Consistindo na apropriação do patrimônio socialmente construído, tanto quanto na atualização das potencialidades de realização humana disponibilizadas em cada contexto historicamente determinado, o conceito de cidadania guarda raízes nas fronteiras que encerram a ideia de soberania popular, implicando a emergência efetiva das condições sociais e institucionais capazes de possibilitar ao conjunto dos cidadãos a participação ativa na formação do governo e, consequentemente, no controle da vida social, convergindo o seu caráter "pleno" para um processo que envolve o exercício dos direitos nas esferas civil, política e social, segundo o contributo do sociólogo britânico T. H. Marshall (1967).

25 "Se a liberdade é irrealizável sem a igualdade, esta, cuja emergência concreta se circunscreve ao âmbito da associação dos homens, não se impõe senão através de uma base material, o que demanda da organização social não menos do que o controle no que concerne à propriedade, que implica uma condição que guarda correspondência com os direitos econômicos atrelados ao exercício da cidadania que, segundo a leitura rousseauniana, envolve uma prática que demanda o referido conteúdo, à medida que traz como base a vontade geral e o interesse comum, tendo em vista a impossibilidade desta inter-relação na esfera de uma sociedade caracterizada pela desigualdade, que pressupõe a prevalência dos interesses privados dos indivíduos em detrimento daquele, o qual, para o bem da coletividade, se lhes deve sobrepor" (MARIANO DA ROSA, 2014, p. 123)
} 
se reduzir ao caráter abstrato de uma construção existente a priori, que transcende, pois, as condições histórico-culturais e econômico-sociais, consiste em uma relação que guarda correspondência com a concreticidade da vida dos homens como subjetividades empíricas e individualidades reais através dos momentos que abrangem a universalidade, a particularidade e a singularidade e perfazem a universalidade de fato, configurando a realidade sociopolítica e -jurídica da totalidade que se impõe à forma institucional do Estado.

Consistindo em um movimento ético-jurídico de objetivação dos valores, necessidades e fins do corpo coletivo e moral que guarda possibilidade de estabelecer uma relação envolvendo o jogo sociocultural e as suas múltiplas circunstâncias, que convergem para as fronteiras que encerram exigências particulares de justiça que escapam ao arcabouço jurídico e se impõem ao processo ético-jurídico de deliberação coletiva e à ação instituinte para a qual tende, a Vontade Geral restitui o conteúdo da forma institucional do Estado, tornando a Constituição e as suas leis expressões da universalidade concreta que lhes cabe como tais.

Se a Vontade Geral consiste, em um momento, em uma espécie de padrão de orientação no que concerne a uma determinada proposição e à sua relação com o bem comum, em outro, subsequentemente, assume a condição de resultado do processo, do qual não emerge senão como a sua declaração (Vontade Geral). Esta é a expressão do interesse comum, guardando as leis, que corporificam os atos gerais, a possibilidade de o indivíduo alcançar no estado social uma condição capaz de correlacionar liberdade, "moralidade" e "virtude", escapando à dependência dos homens e, consequentemente, ao caráter arbitrário de suas vontades e seus interesses particulares (MARIANO DA ROSA, 2015b, p. 19).

Nessa perspectiva, a Vontade Geral vem à tona como um processo ético-jurídico de deliberação coletiva que emerge da solidariedade subjetivo-objetiva dos homens na condição de indivíduos em sua concretude histórico-cultural e econômico-social como membros do corpo coletivo e moral e converge, por meio do movimento econômico-político de objetivação dos valores, necessidades e fins que se lhe impõem, para a integração dinâmico-dialética que perfaz a totalidade sociopolítica e jurídica ora designada como Estado e cuja forma resulta das correlações que abrangem o instituído, o instituinte e a institucionalização.

\section{DA VONTADE GERAL COMO UM PROCESSO ÉTICO-JURÍDICO DE DELIBERAÇÃO COLETIVA E UM MOVIMENTO ECONÔMICO-POLÍTICO DE OBJETIVAÇÃO DO CONTEÚDO DA VIDA HISTÓRICO-CULTURAL E ECONÔMICO-SOCIAL DO CORPO COLETIVO E MORAL: entre a unidade multíplice da sociedade (unitas ordinis) e a totalidade político-jurídica e econômico-social do Estado}

Constituindo-se a superação de um conceito de História que se circunscreve ao simples encontro de indivíduos absolutamente autônomos, os quais, emergindo mediante uma sucessão descontínua, não guardam raízes nem posteridade ou, antes, mudança, a Vontade Geral implica um processo que se sobrepõe à noção de consciência sob a acepção de uma totalidade que se esgota em si em uma conjuntura no âmbito da qual as consciências porventura se imponham como "consciências de si" justapostas, cada qual encerrando, no tocante ao outro, o caráter de uma pura consciência por si, tendo em vista que a sua construção assinala que a condição dos homens não é senão a condição de seres situados, determinados pelo 
tipo de relação que mantêm com os homens, com o mundo e com a natureza em razão do sistema econômico-social em vigor e pela atividade que como indivíduos concretos na esfera das forças produtivas cabem desenvolver, o que os torna titulares de situações que constituem uma situação comum, configurando uma lógica que sublinha que a ação individual não perfaz um evento isolado em uma disposição que se lhe esteja contida em si, mas supõe um compromisso que traz imbricado em seu movimento ou intenção a vida, a existência e o destino de outros.

Se, agora, nos voltarmos para esses atos singulares, veremos neles uma multiplicidade não menos complexa de processos. Sobretudo são atos necessariamente imediatos no processo de reprodução social dos respectivos seres humanos singulares. Que sejam aí respostas primárias que os seres humanos são levados a dar às situações sociais, processos, etc., no interesse de sua autorreprodução, isto também nos é conhecido. Agora importa apenas confirmar o exposto até aqui complementando e, ao mesmo tempo, acrescentando que a almejada, de maneira mais ou menos consciente pelos seres humanos singulares, unificação subjetiva desses seus atos de reação ao ambiente social só pode ser observada, em sua imediaticidade artificialmente a mais simplificada, como atos puramente subjetivos no sentido estrito. Não apenas o que ela desencadeia é, por fim, ocasião para produzir uma "resposta" às questões postas pela sociedade, mas também seu conteúdo, embora sua intenção imediata parta do sujeito enquanto tal, pode ser orientado, sobretudo quanto ao seu teor, para a generidade dos seres humanos concernidos. Como o homem não pode agir em situações humanamente vazias, em cada um dos seus feitos, mesmo nos mais pessoais, como toda tentativa de realização dos seus pensamentos ou sentimentos pessoais partem de comunidades humanas e, de alguma maneira, desemboca nelas, precisamos afirmar com Marx: "O homem é, no sentido mais literal, não um animal social, mas um animal que pode isolar-se apenas em sociedade". Assim, precisamente o teor pessoal mais autêntico de tais decisões na síntese singular e, ainda mais, em sua síntese unificadora da particularidade pessoal na práxis, tem de alguma maneira de orientar-se para os problemas da sociedade existente, tem de incluir o esforço para desempenhar um papel determinado, adequado à personalidade, na generidade nascente, não importa com quais conteúdos e direções conscientes (LUKÁCS, 2010, p. 101 et seq.).

Se uma pluralidade de sujeitos converge para as fronteiras que encerram a "vontade de todos", o que se impõe à Vontade Geral não é senão um processo que implica a intersubjetividade, à medida que, longe da perspectiva que defende que os homens na condição de sujeitos concretos mantêm relações entre si nas quais as "consciências" se expõem como tais (havendo possibilidade de que cada qual exerça a sua individualidade absoluta), o que ocorre é uma ligação que traz como fundamento as ações, implicando uma correspondência envolvendo a totalidade das ações deliberadas ou não, cuja prática e influência porventura alcancem os outros e o mundo, tendo em vista a medida comum que, abrangendo aspectos positivos e aspectos negativos, dialoga respectivamente com uns e com outros em razão da lógica de uma situação comum, constituída, pois, por aqueles que, como titulares, não escapam à regra do jogo, a saber, escolher, independentemente das consequências, como "consciências situadas" que são.

Caso-limite envolvendo as possibilidades de manifestação dos homens como indivíduos em sua concretude histórico-cultural e econômico-social, a Vontade Geral converge para a construção da universalidade concreta (universalidade de fato), a saber, aquela que escapa à 
abstração que se detém nas fronteiras da reflexão, circunscrevendo-se a uma concepção que não guarda raízes na situação vivida, mas pretende superar as particularidades pelo pensamento e pelo procedimento que lhe é próprio, tendo em vista que a superação da universalidade com a qual acena demanda a sua vivência efetiva, à medida que o que se impõe não é senão a necessidade atrelada, pois a sujeitos empiricamente universais, cuja condição não corresponde senão à correlação que abrange o modo de existência particular e a "essência" e a "natureza" que advêm dele, se lhes especificando como tais.

Consistindo na possibilidade de articulação da totalidade dos homens na condição de indivíduos em sua concretude histórico-cultural e econômico-social, a Vontade Geral converge, por meio dos momentos que implicam a universalidade, a particularidade e a singularidade, para a experiência da construção da universalidade de fato, à medida que converte o conteúdo político-social em um poder de direito mediante um processo ético-jurídico que envolve a constituição do Estado como tal, sob a acepção de uma forma institucional capaz de corresponder às necessidades e aos objetivos do corpo coletivo e moral ora designado como povo.

O Estado existe somente como Estado político. A totalidade do Estado político é o poder legislativo. Tomar parte no poder legislativo é, por isso, tomar parte no Estado político, manifestar e realizar sua existência como membro do Estado político, como membro do Estado. Que, portanto, todos singularmente queiram participar no poder legislativo não é senão a vontade de todos de ser membros reais (ativos) do Estado ou de se dar uma existência política ou de manifestar e realizar sua própria existência como existência política (MARX, 2010, p. 132, grifos do autor).

Sobrepondo-se à competência de cada indivíduo entre aqueles que em sua concretude histórico-cultural e econômico-social perfazem o corpo coletivo e moral ora designado como povo, as decisões coletivas consistem em decisões não individuais que emergem de uma totalidade social cujos membros guardam condição de interdependência, a despeito dos antagonismos que caracterizam as relações interindividuais no arcabouço das forças produtivas, o que implica a necessidade da sua superação pelo movimento ético-jurídico de objetivação do conteúdo da vida histórico-cultural e econômico-social do corpo coletivo e moral. Tal movimento ético-jurídico de objetivação encerra um processo lógico-político baseado nos imperativos da Justiça segundo o ideal que, guardando raízes nas fronteiras das contingências históricas, impõe-se às relações intersubjetivas, convergindo para atribuir à ordem jurídica formal da legislação positiva a substancialidade vital que requer a dinâmica de uma forma institucional que não se reduz à uniformidade estática que carrega a noção de um sistema definitivo que, em nome do máximo controle dos movimentos humanos, demanda a adaptação e a normalização dos seus agentes em razão do Estado como totalidade ético-jurídica e econômico-política. ${ }^{26}$

\footnotetext{
${ }^{26}$ Razão pela qual a teoria política de Rousseau assinala que "a declaração da vontade soberana em legislação é por meio da Vontade Geral, que é a única que legitima a Lei. Como súdito, cada indivíduo está subordinado a uma lei em cuja elaboração participou como membro do corpo soberano. Na opinião de Rousseau, nenhuma outra base da lei pode ser legítima. A lei que é proclamada por apenas alguns poucos num Estado impõe servidão àqueles que são compelidos a sujeitar-se-Ihe e não lhes estabelece nenhuma obrigação de obediência" (DENT, 1996, p. 90).
} 
Processo ético-jurídico de deliberação coletiva que converge para um movimento econômico-político de objetivação de valores, necessidades e fins do corpo coletivo e moral por intermédio dos momentos que, envolvendo o instituído, o instituinte e a institucionalização, perfazem a totalidade sociopolítica e jurídica do Estado, à Vontade Geral o que se impõe é a manifestação da unidade multíplice da sociedade (unitas ordinis) que, encerrando simultaneamente conteúdo e forma, produção e reprodução, estabilidade e instabilidade, tende a se sobrepor ao caráter estático da ordem vigente em razão dos motivos econômico-sociais e político-sociais que emergem das relações dos homens como indivíduos concretos entre si e as unidades sociais particulares.

Ao arcabouço de uma forma institucional que se mantém sob condição de ruptura no que tange à sociedade civil e detém a estrutura jurídica que a capacita a controlar os antagonismos envolvendo as vontades particulares e os seus interesses corporificados pelas unidades sociais particulares no jogo das forças produtivas, o que se impõe é a Vontade Geral como um processo ético-jurídico de deliberação coletiva que por meio do movimento econômico-político de objetivação dos valores, necessidades e fins do corpo coletivo e moral converge para um conteúdo que atribui à Constituição e às suas leis a universalidade de fato que a sociedade e a dinâmica das relações intersubjetivas demandam em seu funcionamento. ${ }^{27}$

Nesta perspectiva, a Vontade Geral consiste em um processo ético-jurídico de deliberação coletiva que por meio do movimento econômico-político de objetivação dos valores, necessidades e fins do corpo coletivo e moral converge para a superação da noção de poder social como poder alienado, que escapa aos homens em sua concretude histórico-cultural e econômico-social e se lhes exerce uma relação de exterioridade coercitiva, guardando raízes em uma forma institucional que sem a vitalidade do conteúdo da vida histórico-cultural e econômico-social do povo se esgota como uma totalidade ético-jurídica cuja função restringe-se a determinar a "existência legal" das subjetividades empíricas.

Em geral, pode-se dizer que a distinção entre o conjunto dos homens e outros homens mais especificamente legisladores é dada pelo fato de que este segundo grupo não só elabora diretrizes que se devem tornar norma de conduta para os outros, mas, ao mesmo tempo, elabora os instrumentos através dos quais as próprias diretrizes serão "impostas" e será controlada sua aplicação. Deste grupo, o poder legislativo máximo reside no pessoal estatal (funcionários eleitos e de carreira), que têm à disposição as forças coercivas legais do Estado. Mas não se pode dizer que os dirigentes de organismos e organizações "privadas" também não disponham de sanções coercivas, até a pena de morte. A capacidade máxima do legislador pode-se deduzir do fato de que, à perfeita elaboração das diretrizes, corresponde uma perfeita preparação do consenso "espontâneo" das massas, que devem "viver" aquelas diretrizes, modificando seus hábitos, sua vontade e suas convicções de acordo com aquelas diretrizes e com os objetivos que elas se propõem atingir (GRAMSCl, 2007, p. 302).

Se ao Direito cabe organizar a vida social e as relações que implicam o seu funcionamento, se lhes conferindo a estabilidade necessária, o que demanda a condição essencial que está atrelada à sua estrutura formal e à sua função normativa, o que se impõe à Vontade

\footnotetext{
27 "Quando se propõe uma lei na assembléia do povo, o que se lhes pergunta não é precisamente se aprovam ou rejeitam a proposta, mas se estão ou não de acordo com a vontade geral que é a deles; cada um, dando o seu sufrágio, dá com isso a sua opinião, e do cálculo dos votos se conclui a declaração da vontade geral" (ROUSSEAU, 1999b, p. 205).
} 
Geral é a possibilidade que carrega, como um movimento ético-jurídico de objetivação dos valores e fins do corpo coletivo e moral, no sentido de estabelecer correspondência envolvendo realidades sociais concretas, sobrepondo-se à caracterização do fenômeno jurídico como produto de forças que mecanicamente convergem para a sua manifestação em um exercício que guarda exterioridade concernente aos homens em sua vida efetiva, em sua existência histórico-cultural e econômico-social.

\section{ASPECTOS CONCLUSIVOS}

Da superação das noções envolvendo interioridade e exterioridade que caracterizam as formas institucionais que encerram uma identidade baseada em um conteúdo que, transcendendo os homens na condição de indivíduos em sua concretude histórico-cultural e econômico-social, dialoga com uma perspectiva metafísica e trans-histórica, eis o que se impõe à Vontade Geral cuja emergência, abrangendo os fenômenos propriamente sociais, implica um processo de dessubjetivização que guarda raízes nas fronteiras que alcançam desde as abstrações até as necessidades dos sujeitos como membros do corpo coletivo e moral, conferindo, dessa maneira, a condição de "instituições vivas" aos modos de existência institucionalizados.

A relação envolvendo soberania e Vontade Geral não se impõe senão através de um processo dialético que, guardando raízes no horizonte da organicidade, acena com uma complexidade estrutural cuja constitutividade encerra uma multiplicidade de forças antagônicas, convergindo para as fronteiras da autogestão, que longe de constituir o Estado constitui-se por si o Estado, detentor de um poder que não emerge originariamente como extrassocial, mesmo que aparentemente seja relegado a tal condição ou venha assumi-la como imposição de uma das suas partes constitutivas, o que, em última instância, não se caracteriza senão como uma ruptura. Dessa forma, pois, o sistema autogestionário, em contraposição ao arcabouço que encerra o antagonismo envolvendo Estado e sociedade (ou, segundo a referida dicotomia, o político e o social), constitui um sistema que encerra elementos que, inter-relacionados, legislam em causa própria, esvaziando, desse modo, o sentido que carrega a vontade de todos (maioria), se lhe sobrepondo pela concepção que pretende a reconstrução da sociedade civil e a sua transformação na verdadeira infraestrutura social, que demanda, em última instância, a morte das instituições, a sua transformação ou a inversão de seu sentido, conforme a tendência instaurada pelo poder político autogestor, ao qual cabe possibilitar à sociedade a liberdade de autoinstituição. (ROSA, 2017, p. 56 et seq., grifos do autor)

Nessa perspectiva, o contrato emerge como a institucionalização do próprio povo que dele advém como poder, posto que detentor de uma soberania que se impõe como inalienável, ${ }^{28}$ haja vista que a possibilidade envolvendo a sua suposta transferência por intermédio da representação caracteriza como negativa a associação em questão, à medida que inevita-

\footnotetext{
28 "Na realidade, a soberania, tal como concebe Rousseau, não é a 'força pública', ela é somente a vontade que dirige o emprego dessa força. Segundo o Contrato social, 'a soberania é apenas o exercício da vontade geral'. Segundo o Emílio, 'a essência da soberania consiste na vontade geral'. Essas fórmulas não deixam subsistir nenhum equívoco sobre o verdadeiro pensamento do autor. Por sua natureza, a soberania é única e essencialmente vontade. Se a soberania é indivisível e inalienável, é porque a vontade não se transmite e não se divide" (DERATHÉ, 2009, p. 426, grifos do autor).
} 
velmente acarreta a perda da liberdade e a desigualdade ${ }^{29}$ tendo em vista que constitui uma esfera que tende à independência, sobrepondo ao interesse comum os "interesses privados" em nome de um "bem comum" que prioriza determinados indivíduos ora constitutivos de uma classe em detrimento de outros, perfazendo uma estrutura que em razão da referida hierarquia não converge senão para a legitimação de uma ordem injusta. ${ }^{30}$

Caracterizando-se como a força de coesão que perfaz um todo, a Vontade Geral converge para um conjunto que implica uma tendência que não pode guardar correspondência senão com a sua formação econômico-social, se Ihe escapando qualquer influência externa capaz de determiná-la como tal, tornando-se o interesse comum a sua única possibilidade de expressão, tendo em vista que a preeminência do privado se impõe como um acontecimento que envolve o seu esvaziamento em razão do predomínio das vontades individuais. Dessa forma, a predominância dos interesses individuais, o seu mero somatório, pois, impedindo a constituição da Vontade Geral, não converge senão para enfraquecer a coesão do conjunto, perfazendo uma estrutura cujas partes, não mais do que justapostas, encerram distorções no que respeita à disposição na organização social, que se torna um arcabouço de injustiças e desigualdades. ${ }^{31}$

Se a leitura liberal atribui à democracia a condição que a circunscreve a uma forma constitucional capaz de assegurar, em suma, os direitos aos indivíduos, cumprindo a função de proteger um em relação ao outro no que tange ao seu exercício, cuja capacidade, contudo, baseada em padrões formais e ideais de conduta e comportamento, permanece relegada às fronteiras da liberdade "negativa", ao tipo participativo o que se impõe não é senão a necessidade que implica um processo (educacional) que envolve uma espontânea e ativa participação grupal ou comunitária de indivíduos autônomos. Nesse sentido, a base motivacional que se Ihes determina, guardando correspondência com uma identificação que dispensa qualquer espécie de influência externa e demanda um envolvimento pessoal, emerge como endógena, transcendendo o âmbito de uma organização ou instituição particular, que encerra um conceito e uma dinâmica que tendem a uma lógica funcional, mecanicista, destituída de indícios de humanidade (ROSA, 2017, p. 57).

\footnotetext{
29 "Às relações políticas instauradas através da instituição da sociedade política e do Estado jurídico, o que se impõe é uma formação econômico-social que guarda correspondência com as ações atomísticas dos indivíduos singulares que, trazendo como fundamento um liame constante e necessário entre si, convergem para a emergência de uma finalidade interior que se lhes determina, perfazendo um conjunto organizado que expressa a verdade da vida econômica por intermédio de um corpo daquilo que ora se designa como leis, sob cuja égide a economia monetária advém e impera, resultando, contudo, em um desajuste que tende a introduzir no sistema contradições insuperáveis e antagonismos inelutáveis que culminam na transformação do indivíduo em um meio por intermédio do qual o outro leva a efeito as suas vontades e interesses, tendo em vista o endosso jurídico que as desigualdades alcançam no estado cívico" (MARIANO DA ROSA, 2015a, p. 100 et seq., grifos do autor).

${ }^{30}$ Haja vista que "o poder, instrumento da força coletiva, criado na sociedade para servir de mediador entre o trabalho e o privilégio, encontra-se encadeado fatalmente ao capital e dirigido contra o proletariado. Nenhuma reforma política pode resolver esta contradição, pois, como os próprios políticos o confessam, tal reforma apenas daria mais extensão e energia ao poder e, a menos que se derrube a hierarquia e se dissolva a sociedade, o poder não poderia tocar nas prerrogativas do monopólio. O problema, pois, consiste, para as classes trabalhadoras, não em conquistar, mas sim em vencer ao mesmo tempo o poder e o monopólio, o que significa fazer surgir das entranhas do povo, das profundezas do trabalho uma autoridade maior, um fato mais poderoso, que envolva o capital e o Estado e que os subjugue. Toda a proposição de reforma que não satisfaça a esta condição será apenas um flagelo a mais, uma verga em sentinela, virga vigilantem diria um profeta, que ameaça o proletariado" (PROUDHON, 2003, p. 434).

${ }^{31}$ Nesta perspectiva, cabe recorrer à interpretação de Rousseau envolvendo o processo da instauração da desigualdade que, baseado em três etapas, converge para a institucionalização do estado do rico, do poderoso e do senhor, em contraposição à condição do pobre, do fraco e do escravo: "Se seguirmos o processo da desigualdade nessas diferentes revoluções, verificaremos ter constituído seu primeiro termo o estabelecimento da lei e do direito de propriedade; a instituição da magistratura, o segundo; sendo o terceiro e último a transformação do poder legítimo em poder arbitrário. Assim o estado de rico e de pobre foi autorizado pela primeira época; o de poderoso e de fraco pela segunda; e, pela terceira, o de senhor e escravo, que é o último grau da desigualdade (...)" (ROUSSEAU, 1999a, p. 110).
} 
Se a democracia não consiste senão na realização do corpo coletivo e moral como ordem jurídica, ${ }^{32}$ o que se impõe à Vontade Geral como condição para o seu exercício pelos homens como indivíduos em sua concretude histórico-cultural e econômico-social é a sua capacidade de estabelecer a necessária correspondência envolvendo a construção da democracia como ordem sociopolítica e jurídica, convergindo para a superação de uma relação baseada na universalidade de um Direito que se circunscreve às fronteiras que encerram um "dever-ser", guardando compatibilidade com a noção que supõe uma exterioridade coercitiva cujo efeito emerge sob uma forma institucional de caráter abstrato. Tal forma institucional detém-se em uma igualdade formal no âmbito de uma organização social ${ }^{33}$ constituída por indivíduos que, em virtude das particularidades que perfazem as suas necessidades e da lógica que preside as suas estruturas, acenam com a formação de riquezas que se limita à vida privada, ${ }^{34}$ contemplando uma legislação que traz um conjunto de normas que visam a assegurar o fundamento econômico-social, a saber, a propriedade, ${ }^{35}$ além da divisão do trabalho, ${ }^{36}$ que se lhe é subsequente, o que torna o conceito de polícia preeminente, tendo em vista o status atribuído à segurança da posse, que engendra um contexto incapaz de produzir a experiência da universalidade de fato, relegando o universal ao campo do Direito que, em razão da sua natureza, prescinde do sentido imediato da totalidade político-social que a existência efetiva, real, expõe e reclama, ocultando-se sob a égide da monologal abstração e do papel que demanda das individualidades que se lhe integram no que respeita à elevação da sua consciência ao "universal". ${ }^{37}$

\footnotetext{
32 "A possibilidade de superação da alienação na esfera política, eis o que se impõe à democracia, à medida que se caracteriza como a construção coletiva do espaço público, implicando a plena participação consciente de todos na gestação e no controle do âmbito político, conforme a leitura rousseauniana que envolve a 'soberania popular', constituindo-se a reabsorção dos bens sociais através dos cidadãos um pressuposto democrático que não converge senão para o conceito de cidadania, que se constitui uma capacidade adquirida, seja por alguns indivíduos, seja por todos os indivíduos (no caso de uma democracia efetiva), que implica na apropriação do patrimônio socialmente construído, tanto quanto na atualização das potencialidades de realização humana disponibilizadas em cada contexto historicamente determinado" (MARIANO DA ROSA, 2014, p. 131)

${ }^{33}$ Alcança relevância, nessa perspectiva, a diferenciação envolvendo as concepções políticas de sociedade em questão: "A dicotomia comunidade- associação pode ser ligada a contrastantes concepções políticas de sociedade - como uma livre associação de indivíduos em competição (visão liberal/hobbesiana) ou como um coletivo que é mais que a soma de suas partes, um corpo edificante através do qual é possível concretizar a autêntica cidadania (visão socialista/rousseauniana)" (BOTTOMORE; OUTHWAITE, 1996, p. 116).

${ }^{34}$ Convém salientar a correlação envolvendo liberdade real e igualdade substantiva (material) que, consistindo na base do sistema autogestionário, a leitura proudhoniana estabelece: "A associação livre, a liberdade que se limita a manter a igualdade nos meios de produção e a equivalência nas trocas é a única forma possível de sociedade, a única justa, a única verdadeira" (PROUDHON, 1975, p. 247).

35 "A propriedade privada, enquanto estrutura jurídica, enquanto pertencente ao domínio das superestruturas, tem uma forma e um conteúdo: a 'definição' do Código Civil constitui uma forma; as características mais materiais e concretas de sua 'estrutura' - o modelo metodológico que temos desenvolvido - constituiriam uma forma (...) dotada de um conteúdo" (POULANTZAS, 1965, p. 242).

36 "O trabalho, dividindo-se segundo a lei que lhe é própria e que é a condição primeira de sua fecundidade, atinge a negação de seus fins e destrói-se a si mesmo; em outros termos: A divisão fora da qual não há mais progresso, nem riqueza, nem igualdade, subalterniza o operário, torna a inteligência inútil, a riqueza nociva e a igualdade impossível" (PROUDHON, 2003 , p. 181, grifos do autor).

37 "Em que consiste a especificidade do direito capitalista? Ela não reside na declaração da inviolabilidade do princípio da propriedade privada dos meios de produção (inclusive o solo), já que também em certos modos de produção pré-capitalistas (como o escravista ou o feudal) tal princípio é consagrado pelo direito (as variações possíveis na aplicação desse princípio às práticas econômicas e às relações sociais por elas condicionadas constituindo tão somente diferenças secundárias, e não suscetíveis de descaracterizar o princípio em si mesmo). $O$ aspecto essencial do direito capitalista consiste em atribuir a todos os agentes da produção, independentemente do lugar (proprietário dos meios de produção, trabalhador) que ocupam no processo de produção, a condição de sujeitos individuais de direitos, fixando-os todos como indivíduos livres e iguais, capazes de praticar legitimamente atos de vontade" (SAES, 1998, p. 49).
} 
Nessa perspectiva, se as instituições e as leis positivas tendem a perder a sua vitalidade, não mais correspondendo aos valores, às necessidades e aos objetivos dos homens em sua concretude histórico-cultural e econômico-social, perfazendo um "sistema morto", caracterizado por uma universalidade destituída de conteúdo real, que encerra nas fronteiras da abstração a igualdade e a justiça, se lhes atribuindo uma condição puramente formal, ${ }^{38}$ a Vontade Geral não emerge senão através da oposição incessante que se impõe às relações envolvendo reprodução e produção, forma e conteúdo, relações e normas, perfazendo um processo ético-jurídico que implica o devir histórico e a "essência" da sua realidade, sobrepondo-se à sua representação e aos seus estereótipos, tendo em vista que carrega a possibilidade de estabelecer a unificação da experiência da universalidade concreta (universalidade de fato) ${ }^{39}$, tornando o arcabouço sócio-político-jurídico um "sistema vivo".

Consistindo na superação da ruptura envolvendo a ordem jurídica e a ordem social em uma construção que encerra àquela (ordem jurídica) em condição de exterioridade no que tange a esta última (ordem social) e demanda o controle coercitivo que através do arcabouço normativo se impõe em nome do bem comum da totalidade ético-jurídica e econômico-política corporificada pelo Estado ${ }^{40}$, a Vontade Geral, como um processo ético-jurídico de deliberação coletiva, converge para as fronteiras que encerram uma equivalência substancial entre ambas, à medida que o sistema jurídico emerge como um momento da organização social em uma conjuntura para a qual inevitavelmente tende o movimento econômico-político de objetivação de valores, necessidades e fins que em seu desenvolvimento abrange o instituído, o instituinte e a institucionalização como fases sucessivas que concorrem para resgatar o conteúdo ao qual cabe atribuir o caráter de universalidade de fato à Constituição e às leis.

\footnotetext{
${ }^{38}$ Na medida em que "(...) sob os maus governos essa igualdade é somente aparente e ilusória; serve só para manter o pobre na sua miséria e o rico na sua usurpação. Na realidade, as leis são sempre úteis aos que possuem e prejudiciais aos que nada têm, donde se segue que o estado social só é vantajoso aos homens quando todos eles têm alguma coisa e nenhum tem demais" (ROUSSEAU, 1999b, p. 81).

${ }^{39}$ Encerrando a "união do caráter de reflexo que tem o pensamento com a consequente realização do seu ser um processo", a concepção dialético-materialista da universalidade supera tanto a gnosiologia do materialismo mecanicista quanto o idealismo dialético de Hegel, que converge para uma "mistificação da universalidade", conforme expõe Lukács, que afirma: "A universalidade, sobretudo, não é jamais um ponto de chegada autônomo do pensamento. Marx, na introdução teórica à primeira redação de sua obra econômica, fala de dois caminhos que o conhecimento humano deve percorrer: isto é, da realidade concreta dos fenômenos singulares às mais altas abstrações, e destas novamente à realidade concreta, a qual - com a ajuda das abstrações - pode agora ser compreendida de um modo cada vez mais aproximativamente exato. (...) De fato, o processo de tal aproximação é essencialmente ligado à dialética de particular e universal: o processo do conhecimento transforma ininterruptamente leis que até aquele momento valiam como as mais altas universalidades em particulares modos de apresentação de uma universalidade superior, cuja concretização conduz muito frequentemente, ao mesmo tempo, à descoberta de novas formas da particularidade como mais próximas determinações, limitações e especificações da nova universalidade tornada mais concreta" (LUKÁCS, 1978, p. 103).

40 "Não seria possível pensar um rumo em direção a uma comunidade humana autêntica e verdadeira, que não necessitasse mais das molas do poder, da ganância e da vaidade, mas que estivesse fundada inteiramente na submissão comum a uma lei interiormente reconhecida como necessária e obrigatória? Logo que essa forma de comunidade surgir e se estabelecer, o mal enquanto mal social - e é só este que, como vimos, conta para Rousseau - será superado e eliminado. Se a forma coercitiva de sociedade existente até agora desmoronar e for substituída por uma forma livre de comunidade política e ética - uma forma na qual todos, em vez de estarem submetidos à arbitrariedade dos outros, reconhecem, aprovam e acatam como sua própria apenas a vontade geral - então a hora da redenção chegou. Mas essa redenção espera em vão por ajuda exterior. Nenhum Deus nos pode enviá-la; o homem deve, sim, se transformar no seu próprio salvador e, no sentido ético, no seu criador" (CASSIRER, 1999, p. 74).
} 


\section{REFERÊNCIAS}

BOTTOMORE, T.; OUTHWAITE, W. (org.). Dicionário do pensamento social do Século XX. Tradução Álvaro Cabral e Eduardo Francisco Alves. Rio de Janeiro: Jorge Zahar Ed., 1996.

CASSIRER, Ernst. A questão Jean-Jacques Rousseau. Tradução Erlon José Paschoal e Jézio Gutierre. São Paulo: Unesp, 1999.

CASTORIADIS, Cornelius. A instituição imaginária da sociedade. Tradução Guy Reynaud. 2. ed. Rio de Janeiro: Paz e Terra, 1986.

CASTORIADIS, Cornelius. Socialismo ou barbárie: o conteúdo do socialismo. Tradução Milton Meira do Nascimento e Maria das Graças de Souza Nascimento. São Paulo: Brasiliense, 1983.

DENT, N. J. H. Dicionário Rousseau. Tradução Álvaro Cabral. Rio de Janeiro: Jorge Zahar Ed., 1996.

DERATHÉ, R. Jean-Jacques Rousseau e a ciência política de seu tempo. Tradução Natalia Maruyama. São Paulo: Editora Barcarolla; Discurso Editorial, 2009.

GRAMSCI, Antonio. Cadernos do cárcere: Maquiavel. Notas sobre o Estado e a política. Tradução Luiz Sérgio Henriques, Marco Aurélio Nogueira e Carlos Nelson Coutinho. 3. ed. Rio de Janeiro: Civilização Brasileira, 2007. Vol. 3.

GRAMSCI, Antonio. Escritos políticos. Tradução Manuel Simões. Lisboa: Seara Nova, 1976. Vol. 1. (Col. Universidade Livre).

GUILLERM, Alain; BOURDET, Yvon. Tradução Hélio Pólvora. Autogestão: uma mudança radical. Rio de Janeiro: Zahar, 1976.

KOSIK, Karel. Dialética do concreto. Tradução Célia Neves e Alderico Toríbio. 2. ed. Rio de Janeiro: Paz e Terra, 1976.

LAPASSADE, Georges. Grupos, organizações e instituições. Tradução Henrique Augusto de Araújo Mesquita. 3. ed. Rio de Janeiro: Francisco Alves, 1989.

LOURAU, René. A análise institucional. Tradução Mariano Ferreira. 2. ed. Petrópolis: Vozes, 1996.

LUKÁCS, Georg. Introdução a uma estética marxista: sobre a categoria da particularidade. Tradução Carlos Nelson Coutinho e Leandro Konder. Rio de Janeiro: Civilização Brasileira, 1978. Vol. 33. (Série estética, Col. perspectivas do homem).

LUKÁCS, Georg. Prolegômenos para uma ontologia do ser social: questões de princípios para uma ontologia hoje tornada possível. Tradução Lya Luft e Rodnei Nascimento. São Paulo: Boitempo, 2010.

LUXEMBURGO, Rosa. A Revolução Russa. Tradução Isabel Maria Loureiro. Petrópolis: Vozes, 1991.

MARIANO DA ROSA, L. C. A propriedade como fundamento ético-jurídico e econômico-político em Locke. Hendu - Revista Latinoamericana de Derechos Humanos - UFPA, Belém, PA, v. 6, n. 2, p. 87-102, 2015a.

MARIANO DA ROSA, L. C. A vontade geral como condição para o exercício da soberania popular em Jean-Jacques Rousseau. Revista Sociais e Humanas - UFSM, Santa Maria, RS, v. 28, n. 2, p. 9-23, maio/ago., 2015 b.

MARIANO DA ROSA, L. C. Do direito de ser homem: da alienação da desigualdade social à autonomia da sociedade igualitária na teoria política de Jean-Jacques Rousseau. Pracs: Revista Eletrônica de Humanidades do Curso de Ciências Sociais da Unifap, Macapá, AP, v. 7, n. 2, p. 109-133, jul./dez. 2014.

MARX, Karl. Crítica da filosofia do direito de Hegel. Tradução Rubens Enderle e Leonardo de Deus. 2. ed. rev. São Paulo: Boitempo, 2010.

MÉSZÁROS, István. Para além do capital: rumo a uma teoria da transição. Tradução Paulo Cezar Castanheira e Sérgio Lessa. 1. ed. rev. São Paulo: Boitempo, 2011.

POULANTZAS, Nicos. Nature des Choses et Droit: essai sur dialectique du fait et de la valeur. Paris: Bibliothèque de philosophie du droit, 1965. Vol. 5.

POULANTZAS, Nicos. O Estado, o poder, o socialismo. Tradução Rita Lima. São Paulo: Graal,1981.

POULANTZAS, Nicos. Poder político e classes sociais. Tradução Francisco Silva. São Paulo: Martins Fontes, 1977.

PROUDHON, Pierre Joseph. O que é a propriedade? Tradução Marília Caeiro. 2. ed. Lisboa: Editorial Estampa, 1975.

PROUDHON, Pierre Joseph. Sistema das contradições econômicas ou filosofia da miséria. Tomo I. Tradução J. C. Morel. São Paulo: Ícone, 2003. (Col. Fundamentos de Filosofia).

ROSA, L. C. M. A vontade geral e o sistema autogestionário: necessidade, possibilidade e desafios. Revista ORG \& Demo - Unesp, Marília, SP, v. 18, n. 1, p. 37-60, jan./jun. 2017.

ROUSSEAU, Jean-Jacques. Discurso sobre a origem e os fundamentos da desigualdade entre os homens. Tradução Lourdes Santos Machado. São Paulo: Nova Cultural, 1999a. Vol. II. 
ROUSSEAU, Jean-Jacques. Do contrato social. Tradução Lourdes Santos Machado. São Paulo: Nova Cultural, 1999b. Vol. I.

SAES, Décio. A questão da autonomia relativa do Estado em Poulantzas. Revista Crítica Marxista, Rio de Janeiro: Xamã, n. 7, 1998. 